\title{
PENGARUH BAURAN PEMASARAN, KELOMPOK REFERENSI, KELUARGA, PERAN DAN STATUS TERHADAP KEPUTUSAN PENGGUNAAN KARTU KREDIT (STUDI PADA ANGGOTA IDI MALANG)
}

\author{
Matheous Tamonsang \\ Email: tamonsangmatheous@yahoo.com \\ Fakultas Ekonomi Dan Bisnis, Universitas Wijaya Kusuma Surabaya \\ Maqbulla Arrochman \\ Email : ula_aro@yahoo.co.id \\ Fakultas Ekonomi Dan Bisnis, Universitas Wijaya Kusuma Surabaya
}

\begin{abstract}
A credit card is a payment instrument that can be used by the public to transact. The consumer's decision to use a credit card appears when there are needs and desires that must be fulfilled, so that marketers must learn about consumer behavior. The aimed of this study was to prove the impact of marketing mix, reference group, family, role and status to usage decision of credit car.

The population in this study was Malang people who used credit cards. The results showed that the marketing mix, reference group, family, and the role and status simultaneously influenced usage decision of credit cards. Of the four independent variables, only reference groups and roles and statuses had a partial effect on credit card usage decisions.
\end{abstract}

Keywords:marketing mix, reference group, family, role and status, usage decision

\section{PENDAHULUAN}

Perkembangan penggunaan kartu kredit yang begitu pesat ini disebabkan karena sebagian dari masyarakat merasakan semakin pentingnya penggunaan kartu kredit sebagai alat bantu pembayaran dan penganti dariuang tunai mengingat kepraktisa rasa nyaman dan aman yang ditimbulkan. Menurut Tambunan (2001) perilaku penggunaan kartu kredit secara berlebihan dalam hubungannya dengan tindakan pembelian suatu barang dan jasa yang sebenarnya kurang diperlukan sehingga lebih pada tujuan pemenuhan kepuasan. Perilaku dan kepribadian seseorang dalam pengendalian diri terhadap penggunaan kartu kredit secara berlebihan harus menjadi pertimbangan, pentingnya kemampuan untuk dapat mengendalikan diri dengan baik dalam proses pembelian barang akan memberikan pelajaran bahwa pengendalian menjadi sangat bermanfaat agar tidak membawa dampak negatif pada saat menggunakan kartu kredit.

Kota Malang sebagai salah satu kota besar yang penduduknya sangat komplek dimana kehidupan yang penuh kesibukan membuat orang cenderung menginginkan yang serba cepat, mudah dan praktis termasuk untuk kegiatan yang bersifat konsumtif. Fenomena ini oleh pihak bank selaku penerbit kartu kredit dijadikan acuan untuk menawarkan kepraktisan dan keamanan dalam berbelanja. Adanya kartu kredit ini bagi sebagian orang benar-benar mendukung gaya hidup yang dianutnya, sehingga mereka memanfaatkan pada hampir semua transaksi pembelian barang atau jasa. Sebagian lainnya walaupun memakai kartu kredit, hanya memanfaatkan sekali-kali saja, namun masih ada pula orang yang tetap menganut gaya hidup tradisional yang lebih senang membayar tunai untuk segala sesuatu yang dibelinya.

Keputusan konsumen untuk menggunakan kartu kredit muncul apabila terdapat kebutuhan dan keinginan yang harus dipenuhi, sehingga para pemasar harus mempelajari perilaku konsumen. Mempelajari perilaku konsumen berarti meneliti lingkungan individu konsumen yang akan mempengaruhi keputusan, sedangkan menganalisisi pasar konsumen berarti meneliti program bauran pemasarannya. Sehingga bisa dikatakan bahwa pola konsumsi dengan menggunakan kartu kredit ada kaitannya dengan lingkungan individual yang terdiri dari kelompok referensi, keluarga, peran dan status dan program pemasaran bank.

Berdasar latar belakang diatas maka rumusan masalah dalam penelitian ini adalah apakah bauran pemasaran dan lingkungan individu yang terdiri dari kelompok referensi, keluarga, peran dan status berpengaruh terhadap keputusan penggunakan 
kartu kredit (Studi pada Anggota IDI Malang)? Alasan menggunakan anggota IDI (Ikatan Dokter Indonesia) karena sebagai seorang dokter yang bekerja dengan kesiapsiagaan yang cukup tinggi dalam melayani pasien selalu membutuhkan alat pembayaran yang cepat untuk berbagai transaksi baik yang berkaitan dengan pekerjaan maupun untuk keperluan pribadi. Sedangkan bila dilihat dari sisi kelayakan, secara ekonomi profesi dokter cukup layak untuk mendapatkan fasilitas kredit non tunai.

\section{Bauran Pemasaran ( Marketing Mix )}

Menurut Hurriyati (2010) bauran pemasaran (bauran pemasaran) yaitu merupakan unsur-unsur pemasaran yang saling terkait, dibaurkan, diorganisir dan digunakan dengan tepat, sehingga perusahaan dapat mencapai tujuan pemasaran dengan efektif, sekaligus memuaskan kebutuhan dan keinginan konsumen.

Menurut Kotler dan Amstrong (2012), marketing mix merupakan seperangkat alat pemasaran yang digunakan perusahaan untuk terus menerus mencapai tujuan perusahaannya di pasar sasaran. Sedangkan Swastha (2008) menyatakana marketing mix adalah kombinasi dari empat variabel atau kegiatan yang merupakan inti dari sistem pemasaran perusahaan, yakni : produk, struktur harga, kegiatan promosi, dan sistem distribusi.

Program pemasaran yang efektif memadukan seluruh elemen bauran pemasaran kedalam suatu program terpadu yang didesain untuk mencapai tujuan pemasaran perusahaan melalui penyampaian nilai (value delivery) kepada para pelanggan atau konsumen. Bauran pemasaran menciptakan seperangkat alat taktis perusahaan untuk membangun posisi yang kuat didalam pasar sasaran.

Elemen marketing mix menurut Tjiptono (2008) mengemukakan konsep bauran pemasaran jasa terdiri dari 7P yaitu :

a. Product (produk), adalah segala sesuatu yang dapat ditawarkan kesuatu pasar untuk memenuhi segala keinginan dan kebutuhan konsumen.

b. Price (harga), merupakan sejumlah uang yang harus dikeluarkan konsumen untuk memperoleh produk/jasa yang dihasilkan perusahaan.

c. Place (tempat/lokasi), adalah berbagai kegiatan yang dilakukan peusahaan agar produk/jasa dapat diperoleh dan tersedia bagi pasar sasaran. d. Promotion (promosi), semua kegiatan yang dilakukan untuk mengkomunikasikan dan mempromosikan produk/jasa kepasar sasaran.

e. People (orang), yaitu semua pelaku yang memainkan perana dalam penyajian jasa sehingga dapat mempengaruhi persepsi pembelian.

f. Process (proses), yaitu seluruh aktivitas kerja dimana melibatkan prosedur tugas-tugas, jadwal-jadwal, mekanisme-mekanisme, aktivitas-aktivitas dan rutinitas-rutinitas dengan apa produk (barang atau jasa) disalurkan ke pelanggan.

g. Physical evidence (bukti fisik), yaitu lingkungan fisik dimana jasa disampaikan dan dimana perusahaan dan konsumennya berinteraksi. Dan setiap komponen tangible memfasilitasi penampilan atau komunikasi jasa tersebut.

\section{Pengaruh Bauran Pemasaran Jasa Terhadap Keputusan Pembelian}

Menurut Kotler dan Amstrong (2012), Bauran pemasaran merupakan seperangkat alat pemasaran yang digunakan perusahaan untuk terus menerus mencapai tujuan perusahaannya di pasar sasaran. Zeithaml (2006) menyatakan keterkaitan elemenelemen bauran pemasaran dengan keputusan pembelian sebagai berikut : Elemen-elemen bauran pemasaran yang terdiri dari produk, harga, tempat, promosi, bukti fisik, dan proses merupakan elemen-elemen yang dapat dikontrol oleh perusahaan, yang ditujukan untuk memuaskan keinginan dan berkomunikasi dengan pelanggan. Dengan begitu, elemen-elemen bauran pemasatan tersebut akan mempengaruhi bagaimana pelanggan mengambil tindakan untuk memenuhi keinginan melalui tahapan dalam proses pembuatan keputusan.

Selanjutnya bauran pemasaran jasa dalam kaitannya dengan keputusan konsumen yang akhirnya berpengaruh terhadap penjualan menurut Swastha dan Sukotjo (2002) sebagai berikut: bahwa penjualan merupakan fungsi yang paling penting dalam pemasaran karena menjadi tulang punggung kegiatan untuk mencapai pasar yang dituju. Fungsi penjualan merupakan sumber pendapatan yang diperlukan untuk menutupi ongkos-ongkos dengan harapan untuk mendapatkan laba. Jika barang-barang diproduksi atau dibeli untuk dijual, maka harus diusahakan sejauh mungkin agara barang tersebut dapat terjual. Oleh karena itu perlu adanya berbagai 
macam cara untuk memajukan penjualan, dianataranya dengan mengatur bauran pemasaran.

Berdasarkan beberapa pendapat para ahli diatas, ada hubungan yang jelas antara bauran pemasaran jasa dengan keputusan konsumen untuk membeli produk atau jasa perusahaan, yang selanjutnya meningkatkan hasil penjualan produk atau jasa perusahaan.

\section{Pengaruh Lingkungan Sosial Terhadap Keputusan Pembelian}

Terdapat dua aspek eksternal yang mempengaruhi pengambilan keputusan yaitu aspek pemasaran perusahaan dan aspek lingkungan sosial budaya (Schifman dan Kanuk: 2007). Melalui input kedua aspek eksternal tersebut, individu secara komprehensif internal memproses input bersamaan dengan pengalaman, kebutuhan dan keinginan psikologis yang dimilikinya.

Aspek sosial (lingkungan individu konsumen) yang dimaksud disini menurut Kotler (2000) kelompok acuan/referensi, keluarga, serta peran dan status. Kelompok referensi menurut Olson (1999) melibatkan satu atau lebih orang yang dijadikan sebagai dasar pembanding atau titik referensi dalam membentuk tanggapan afeksi atau kognisi serta menyatakan perilaku seseorang. Grup referensi seseorang dapat berasal dari status sosial, sub budaya atau bahkan budaya yang sama atau berbeda. Didalam grup biasanya terdapat seorang opinion leader yang dapat berfungsi sebagai sumber informasi yang bersifat informal dan berpengaruh terhadap pengambilan keputusan.

Sedangkan Kotler (2000) menyatakan keluarga yaitu dua atau lebih orang yang dihubungkan oleh garis keturunan atau perkawinan yang memiliki pertalian darah. Seseorang merupakan anggota berbagai kelompok.Posisi seseorang dalam setiap kelompok dapat ditetapkan baik lewat perannya maupun statusnya dalam organisasi tersebut. Setiap peran membawa status yang mencerminkan penghargaan yang diberikan oleh masyarakat. Seseorang seringkali memilih produk yang menunjukkan status mereka dalam masyarakat.

\section{Penelitian Sebelumnya}

Penelitian sebelumnya pernah dilakukan oleh Irwinda N.T. Andi Lolo (2011) mengenai pengaruh bauran pemasaran terhadap keputusan konsumen yang menabung di bank Mandiri (Persero) Tbk, Cabang Makasar. Penelitian lainnya yang sejenis dilakukan oleh Sulistyawaty, mengenai perilaku konsumen dalam menggunakan kartu kredit di wilayah DKI Jakarta. Dan juga penelitian yang telah dilakukan oleh Rizal (2010) mengenai pengaruh grup referens dan keluarga terhadap keputusan pembelian ponsel.

\section{Hipotesis}

Berdasarkan pendahuluan, latar belakang, landasan teori dan penelitian sebelumnya, maka hipotesis dalam penelitian ini adalah sebagai berikut :

1. Bauran pemasaran, kelompok referensi, keluarga, peran dan status terhadap keputusan penggunaan kartu kredit (studi pada anggota IDI Malang).

2. Kelompok referensi mempunyai pengaruh dominan terhadap keputusan penggunaan katru kredit (studi pada anggota IDI Malang).

\section{Kerangka Konseptual}

Model analisis yang digunakan dalam penelitian ini dapat digambarkan sebagai berikut:



\section{Gambar 1 \\ Kerangka Konseptual}

\section{METODE PENELITIAN \\ Populasi dan Sampel \\ Populasi}

Menurut Malhotra (2009) Populasi adalah gabungan seluruh elemen, yang memiliki serangkaian karakteristik serupa, yang mencakup semesta untuk kepentingan masalah riset pemasaran. Populasi dalam penelitian ini adalah masyarakat Malang yang menggunakan kartu kredit. 


\section{Sampel}

Menurut Malhotra (2009) sampel adalah subkelompok elemen populasi yang terpilih untuk berpartisipasi dalam studi. Sample dalam penelitian ini adalah anggota IDI Malang yg menggunakan kartu kredit secara aktif. Teknik sampling yang digunakan purposive sampling yaitu penentuan sample dengan kriteria tertentu. Kriteria responden yang digunakan dalam adalah anggota IDI Malang aktif, menggunakan kartu kredit secara aktif dan berdomisili di kota Malang, dengan jumlah sample sebanyak 70 orang yang kebetulan dapat ditemui dan bersedia mengisi kuesioner ditengah kesibukan mereka sebagai dokter.

\section{Identifikasi Variabel}

Identifikasi Variabel yang digunakan dalam penelitian ini sebagai berikut :

1. Variabel Bebas (X), adalah variabel yang menjadi sebab pengaruh atau berubahnya variabel terikat. Dalam penelitian ini variabel bebas adalah :
a. Bauran pemasaran $\left(\mathrm{X}_{1}\right)$
b. Kelompok referensi $\left(\mathrm{X}_{2}\right)$
c. Keluarga $\left(\mathrm{X}_{3}\right)$
d. Peran dan status $\left(\mathrm{X}_{4}\right)$

2. Variabel Terikat (Y), adalah variabel yang menjadi akibat karena adanya variabel bebas. Variabel terikat dalam penelitian ini adalah keputusan penggunaan kartu kredit.

\section{Definisi Operasional}

Definisi operasional untuk variabel yang digunakan dalam penelitian ini yaitu:

1. Bauran pemasaran $\left(\mathrm{X}_{1}\right)$

Bauran pemasaran merupakan alat pemasaran yang dijadikan strategi dalam kegiatan perusahaan guna mencapai tujuan perusahaan. Indikator:

a. Product, sesuatu yang dapat ditawarkan ke pasar untuk diperhatikan, dipakai, dimiliki, atau dikonsumsikan sehingga dapat memuaskan keinginan atau kebutuhan.

b. Price, suatu nilai tukar yang bisa disamakan dengan uang atau barang lain untuk manfaat yang diperoleh dari suatu barang atau jasa bagi seseorang atau kelompok pada waktu tertentu dan tempat tertentu.

c. Place, dalam konteks ini merupakan lokasi yang memungkinkan bagi setiap transaksi dengan menggunakan kartu kredit.

d. Promotion, adalah upaya untuk memberitahukan atau menawarkan produk atau jasa dengan tujuan menarik calon konsumen untuk menggunakan kartu kredit.

e. People, adalah semua pelaku yang memainkan peran penting dalam penyajian jasa sehingga dapat mempengaruhi persepsi pembeli.

f. Process, adalah kegiatan yang menunjukkan bagaimana pelayanan diberikan kepada konsumen selama menggunakan kartu kredit.

g. Physical Evidence, merupakan lingkungan fisik tempat jasa diberikan.

2. Kelompok referensi $\left(\mathrm{X}_{2}\right)$

Kelompok Referensi merupakan sekelompok orang yang dianggap memiliki pengaruh evaluasi, aspirasi, bahkan perilaku terhadap orang lain secara langsung ataupun tidak langsung, dan dianggap sebagai pembandingan bagi seseorang dalam membentuk nilai dan sikap umum/khusus atau pedoman khusus bagi perilaku.

Indikator:

a. Kepentingan menjaga norma kelompok terhadap penggunaan kartu kredit.

b. Meningkatkan citra diri terhadap penggunaan kartu kredit.

c. Komunikasi word of mouth terhadap penggunaan kartu kredit.

d. Pengaruh pemimpin opini terhadap penggunaan kartu kredit.

3. Keluarga $\left(X_{3}\right)$

Keluarga merupakan sekumpulan orang dengan ikatan perkawinan, kelahiran dan adopsi yang bertujuan untuk menciptakan, mempertahankan budaya dan meningkatkan perkembangan fisik, mental, emosional serta sosial dari tiap anggota keluarga.

a. Pemenuhan kebutuhan keluarga terhadap penggunaan kartu kredit.

b. Keterlibatan suami/istri terhadap penggunaan kartu kredit.

c. Pengambil keputusan dominan untuk menggunakan kartu kredit.

4. Peran dan status $\left(\mathrm{X}_{4}\right)$

Peran adalah kegiatan seseorang untuk diakui keberadaannya yang didukung dengan penghargaan dari umum atau kelompok masyarakat terhadap seseorang.

Indikator:

a. Pengaruh peran keluarga terhadap pengguna kartu kredit.

b. Menggunakan kartu kredit sebagai bagian gaya hidup. 
c. Menggunakan kartu kredit karena kemudahan transaksi.

d. Menggunakan kartu kredit karena prestise.

5. Keputusan Penggunaan Kartu Kredit (Y)

Keputusan penggunaan kartu kredit merupakan sebuah tindakan yang dilakukan konsumen untuk menggunakan kartu kredit.

a. Memutuskan untuk menggunakan kartu kredit.

b. Keyakinan bahwa keputusan menggunakan kartu kredit merupakan keputusan yang tepat.

c. Untuk menentukan nilai dan jawaban atas setiap pertanyaan dalam kuesioner digunakan skala Likert 5 poin yaitu :
1. Sangat setuju
2. Setuju
3. Netral
4. Tidak setuju
5. Sangat tidak setuju

\section{Jenis dan Sumber Data}

Data yang digunakan dalam penelitian ini adalah pertama, data Primer yaitu data yang diperoleh langsung dari responden dengan cara menyebarkan kuesioner. Kedua, data sekunder yaitu data yang diperoleh dari sumber- sumber yang ada di literature-literatur yang berkaitan dengan penelitian.

\section{Tehnik Analisa Data dan Uji Hipotesis}

Dalam penelitian ini pengolahan dilakukan dengan bantuan SPSS (Statistical Product Service Solutions) versi 17 sebagai alat menganalisis data. Analisis diawali dengan melakukan uji kualitas data yang terdiri atas uji validitas dan uji realibilitas pada setiap item pertanyaan dalam kuesioner. Selanjutnya data yang terkumpul dilakukan analisis regresi linier sederhana dan uji hipotesis berupa uji $t$, koefisien korelasi dan koefisien determinasi.

\section{PEMBAHASAN}

Analisis Regresi Linier Berganda

Analisis linier berganda dimaksudkan untuk menganalisis pengaruh variabel bauran pemasaran, kelompok referensi, keluarga, peran dan status terhadap keputusan pengguna kartu kredit. Data yang telah diuji validitas dan realibilitas kemudian dianalisis dengan regresi linier berganda. Berdasarkan hasil perhitungan SPSS 17 diperoleh persamaan regresi linier sebagai berikut yaitu :

$$
\begin{aligned}
& Y=-2,041+0,032 . X_{1}+0,238 . X_{2}+0,185 . X_{3}+ \\
& 0,199 . X_{4}+e
\end{aligned}
$$

Tabel 1

Koefisien Regresi

\begin{tabular}{cccc}
\hline Variabel & $\begin{array}{c}\text { Unstandardized } \\
\text { Coefficients (B) }\end{array}$ & Sig. & Kesimpulan \\
\hline (Constant) & $-2,041$ & 0,095 & Tidak Signifikan \\
\hline $\mathrm{X}_{1}$ & 0,032 & 0,335 & Tidak Signifikan \\
\hline $\mathrm{X}_{2}$ & 0,238 & 0,016 & Signifikan \\
\hline $\mathrm{X}_{3}$ & 0,185 & 0,074 & Tidak Signifikan \\
\hline $\mathrm{X}_{4}$ & 0,199 & 0,012 & Signifikan \\
\hline $\mathrm{R}^{2}$ & 0,785 & 0,785 & \\
\hline $\mathrm{F}_{\mathrm{Sig}}$ & 59,440 & 0,000 & \\
\hline $\mathrm{N}$ & 70 & \\
\hline Variabel Dependen : Keputusan Pengguna \\
\hline
\end{tabular}

Persamaan Regresi di atas dapat dijelaskan sebagai berikut :

a. Pengaruh Bauran Pemasaran Terhadap Keputusan Penggunaan

Koefisien regresi gaya hidup sebesar 0,032, artinya semakin tinggi persepsi responden terhadap bauran pemasaran kartu kredit maka keputusan penggunaan semakin meningkat untuk menggunakan kartu kredit, begitu sebaliknya penurunan persepsi responden terhadap bauran pemasaran kartu kredit maka keputusan penggunaan kartu kredit menjadi semakin menurun.

b. Pengaruh Kelompok Referensi Terhadap Keputusan Penggunaan

Koefisien regresi kelompok referensi sebesar 0,238, artinya semakin tinggi persepsi responden terhadap kelompok referensi yang telah menggunakan kartu kredit maka keputusan penggunaan semakin meningkat untuk menggunakan kartu kredit, begitu sebaliknya penurunan persepsi responden 
terhadap kelompok referensi yang telah menggunakan kartu kredit maka keputusan penggunaan kartu kredit menjadi semakin menurun.

c. Pengaruh Keluarga Terhadap Keputusan Penggunaan

Koefisien regresi Keluarga sebesar 0,185, artinya semakin tinggi persepsi responden terhadap keluarga yang telah menggunakan kartu kredit maka keputusan penggunaan semakin meningkat untuk menggunakan kartu kredit, begitu sebaliknya penurunan persepsi responden terhadap keluarga yang telah menggunakan kartu kredit maka keputusan penggunaan kartu kredit menjadi semakin menurun.

d. Pengaruh Peran dan Status Terhadap Keputusan Penggunaan.

Koefisien regresi gaya hidup sebesar 0,199, artinya semakin tinggi persepsi responden terhadap Peran dan Status sebagai pengguna kartu kredit maka keputusan penggunaan semakin meningkat untuk menggunakan kartu kredit, begitu sebaliknya penurunan persepsi responden terhadap Peran dan Status sebagai pengguna kartu kredit maka keputusan penggunaan kartu kredit menjadi semakin menurun.

\section{Pengujian Hipotesis \\ Uji Simultan}

Uji $F$ dilakukan untuk menguji signifikansi dari variable-variabel terikat yang terdiri dari bauran pemasaran $\left(\mathrm{X}_{1}\right)$, kelompok referensi $\left(\mathrm{X}_{2}\right)$, keluarga $\left(\mathrm{X}_{3}\right)$ dan peran status $\left(\mathrm{X}_{4}\right)$ terhadap pengguna kartu kredit anggota IDI di Malang. Berdasarkan tabel dapat diketahui bahwa uji $F$ dengan menggunakan SPSS diperoleh Fhitung sebesar 59,440 dengan tingkat signifikansi 0,000 lebih kecil disbanding taraf signifikan sebesar 5\% atau 0,05 maka dapat dikatakan bahwa bauran pemasaran $\left(\mathrm{X}_{1}\right)$, kelompok referensi $\left(\mathrm{X}_{2}\right)$, keluarga $\left(\mathrm{X}_{3}\right)$ dan peran status $\left(\mathrm{X}_{4}\right)$ berpengaruh signifikan secara simultan terhadap pengguna kartu kredit anggota IDI di Malang.

\section{Uji Parsial}

Uji T dilakukan untuk menguji hipotesis pertama yaitu mengetahui signifikansi pengaruh variabel independen yang terdiri dari bauran pemasaran $\left(\mathrm{X}_{1}\right)$, kelompok referensi $\left(\mathrm{X}_{2}\right)$, keluarga $\left(\mathrm{X}_{3}\right)$ dan peran status $\left(\mathrm{X}_{4}\right)$ terhadap pengguna kartu kredit anggota IDI di Malang secara parsial atau individual.

a. Pengaruh bauran pemasaran terhadap keputusan pengguna

Hasil pengujian pada tabel diperoleh nilai signifikansi sebesar 0,335 yang lebih besar dari 0,05 , artinya bauran pemasaran tidak berpengaruh signifikan terhadap keputusan pengguna kartu kredit anggota IDI di Malang

b. Pengaruh kelompok referensi terhadap keputusan pengguna

Hasil pengujian pada tabel diperoleh nilai signifikansi sebesar 0,016 yang lebih kecil dari 0,05 , artinya kelompok referensi berpengaruh signifikan terhadap keputusan pengguna kartu kredit anggota IDI di Malang

c. Pengaruh keluarga terhadap keputusan pengguna Hasil pengujian pada tabel diperoleh nilai signifikansi sebesar 0,074 yang lebih besar dari 0,05 , artinya keluarga tidak berpengaruh signifikan terhadap keputusan pengguna kartu kredit anggota IDI di Malang

d. Pengaruh peran dan status terhadap keputusan pengguna Hasil pengujian pada tabel diperoleh nilai signifikansi sebesar 0,012 yang lebih besar dari 0,05 , artinya peran dan status tidak berpengaruh signifikan terhadap keputusan pengguna kartu kredit anggota IDI di Malang

\section{Analisis Standardized Coefficient Beta}

Analisis standardized coefficient beta digunakan untuk mengukur kemampuan model dalam menerangkan variabel dependen. Hasil Perhitungan dapat dilihat pada Tabel 2. Berdasarkan tabel diperoleh nilai Beta terbesar terjadi pada variabel peran dan status, artinya bahwa pengaruh paling besar terhadap variabel keputusan pengguna kartu kredit, terjadi pada variabel peran dan status. Sehingga hipotesis kedua, dapat diterima kebenarannya.

Tabel 2

Analisa Pengaruh Dominan

\begin{tabular}{cc}
\hline Variabel & Unstandardized Coefficients (B) \\
\hline $\mathrm{X}_{1}$ & 0,129 \\
\hline $\mathrm{X}_{2}$ & 0,243 \\
\hline $\mathrm{X}_{3}$ & 0,242 \\
\hline $\mathrm{X}_{4}$ & 0,343 \\
\hline Variabel Dependen : Keputusan Pengguna \\
\hline
\end{tabular}




\section{Diskusi}

Hasil uji regresi diperoleh bahwa bahwa bauran pemasaran $\left(\mathrm{X}_{1}\right)$, kelompok referensi $\left(\mathrm{X}_{2}\right)$, keluarga $\left(\mathrm{X}_{3}\right)$ dan peran status $\left(\mathrm{X}_{4}\right)$ berpengaruh signifikan secara simultan terhadap keputusan pengguna kartu kredit anggota IDI di Malang. Hal ini menunjukkan bahwa keberadaan keempat variabel tersebut sangat menentukan keputusan pengguna kartu kredit anggota IDI di Malang. Hal ini didasari oleh semakin tingkat mobilitas masyarakat khususnya yang memiliki profesi pekerjaan yang sangat padat seperti dunia kedokteran, membuat mereka tidak memiliki waktu untuk mengambil uang dan melakukan transaksi secara tunai terlebih bila posisi kas tabungan mereka tanpa disadari sudah tidak dapat didebet. Bila keempat variabel tersebut tidak ada, maka keputusan pengguna kartu kredit akan negative yang ditunjukkan dengan besarnya nilai koefisien regresi constant yang merupakan kecenderungan pengaruh dari variabel bebas lain di luar model.

Golongan masyarakat tersebut sangat membutuhkan alat pembayaran yang dapat mengatasi beberapa permasalahan seperti di atas, walaupun dalam setiap transaksinya ada beban bunga yang cukup tinggi. Mereka tidak mempermasalahkan sejauh transaksi bisa dilaksanakan dengan lancar, seperti pemesanan alat-alat medis termasuk obat-obatan darurat yang berharga cukup tinggi untuk menunjang kegiatan praktek mereka demi tanggungjawab mereka untuk menyembuhkan pasien yang notabene tidak ada kata terlambat dalam menangani pasien.

Walaupun secara simultan, keempat variabel bebas tersebut mempunyai pengaruh yang signifikan terhadap keputusan pengguna kartu kredit, tetapi ternyata di antara keempat variabel tersebut, hanya ada dua variabel yang memiliki pengaruh signifikan secara parsial terhadap terbentuknya keputusan pengguna kartu kredit yaitu kelompok referensi $\left(\mathrm{X}_{2}\right)$ dan peran status $\left(\mathrm{X}_{4}\right)$. Hal ini lebih dikarenakan bahwa memilih kartu kredit yang dapat mengakomodasi kepentingan penggunanya serta memberikan rasa aman dalam bertransaksi adalah merupakan suatu hal yang tidak mudah. Kesulitan yang dihadapi adalah untuk mendapat kartu kredit yang memberikan fasilitas yang lebih, belum tentu merupakan kartu kredit yang terbaik dan memberi rasa aman. Untuk itu, sebagai masyarakat yang mempunyai profesi berintelektual seperti dokter sangatlah berhati- hati untuk memilih kartu kredit yang terlebih dahulu mencari informasi dari kelompok referensi terutama dari teman yang mempunyai profesi yang sama dan keluarga mereka yang telah terlebih dahulu memiliki kartu kredit yang dimaksud.

Selain kelompok referensi, variabel peran dan status juga berpengaruh signifikan terhadap keputusan pengguna kartu kredit bagi anggota IDI di Malang. Hal ini lebih dikarenakan bahwa memiliki kartu kredit dengan limit yang tinggi bahkan yang tidak terbatas telah membuat mereka lebih percaya diri karena merasa mempunyai kredibilitas yang sangat tinggi di mata masyarakat. Alasan tersebut yang mendasari adalah peran mereka sebagai dokter lebih dihargai dan status social mereka menjadi lebih tinggi di mata masyarakat yang telah terbentuk persepsi bahwa mereka dapat menjalankan kewajiban mereka sebagai seorang dokter yang professional dengan mendapat dukungan dana dari pihak Bank. Selain itu tugas mereka yang biasanya tergabung dalam organisasi professional sering melaksanakan kegiatan seminar atau memenuhi undangan profesi yang lebih banyak dilaksanakan di luar kota maupun di luar negeri. Hal inilah yang membuat variabel peran dan status menjadi variabel yang mempunyai pengaruh dominan untuk membentuk keputusan pengguna kartu kredit anggota IDI di Malang.

\section{PENUTUP \\ Simpulan}

Berdasarkan hasil pengolahan data dalam penelitian ini dapat ditarik kesimpulan berikut:

1. Dengan uji $F$ diperoleh $F_{\text {hitung }}$ sebesar 59,440 dengan tingkat signifikansi 0,000 lebih kecil dibanding taraf signifikan sebesar $5 \%$ atau 0,05 maka dapat dikatakan bahwa bauran pemasaran $\left(\mathrm{X}_{1}\right)$, kelompok referensi $\left(\mathrm{X}_{2}\right)$, keluarga $\left(\mathrm{X}_{3}\right)$ dan peran status $\left(\mathrm{X}_{4}\right)$ berpengaruh signifikan secara simultan terhadap pengguna kartu kredit anggota IDI di Malang.

2. Diantara keempat variabel bebas yaitu bauran pemasaran $\left(\mathrm{X}_{1}\right)$, kelompok referensi $\left(\mathrm{X}_{2}\right)$, keluarga $\left(\mathrm{X}_{3}\right)$ dan peran status $\left(\mathrm{X}_{4}\right)$, variabel yang berpengaruh signifikan secara parsial terhadap pengguna kartu kredit anggota IDI di Malang adalah variabel kelompok referensi $\left(\mathrm{X}_{2}\right)$ dan peran status $\left(\mathrm{X}_{4}\right)$. 
3. Variabel yang mempunyai pengaruh terbesar terhadap pengguna kartu kredit anggota IDI di Malang adalah Peran Status $\left(\mathrm{X}_{4}\right)$.

\section{Saran}

Dari hasil penelitian, pembahasan, serta kesimpulan diberikan saran sebagai berikut:

1. Hendaknya dunia perbankan yang menerbitkan kartu kredit mempertimbangkan keberadaan variabel bauran pemasaran $\left(\mathrm{X}_{1}\right)$, kelompok referensi $\left(\mathrm{X}_{2}\right)$, keluarga $\left(\mathrm{X}_{3}\right)$ dan peran status $\left(\mathrm{X}_{4}\right)$ yang ternyata berpengaruh signifikan secara simultan terhadap pengguna kartu kredit anggota IDI di Malang. Bila tidak mendapat perhatian, maka tidak ada keputusan untuk menggunakan kartu kredit tersebut.

2. Konsistensi keamanan dan kenyamanan untuk bertransaksi dengan menggunakan kartu kredit harus mendapat jaminan dari dunia perbankan agar mereka terutama yang berprofesi sebagai dokter dapat menjalankan tugasnya dengan baik.

3. Untuk penelitian selanjutnya, sebaiknya memperluas indikator dari masing- masing variabel yang digunakan dalam penelitian ini dalam meningkatkan kepuasan pelanggan kartu kredit anggota IDI Malang dan masyarakat umumnya.

\section{DAFTAR PUSTAKA}

Alma, Buchari. 2014. Manajemen Pemasaran dan Pemasaran Jasa. CV. Alpabet. Bandung

Engel, F. James, Roger D Blackwell, and Paul W. Miniard. 2001. Perilaku Konsumen. Terjemahan Alex Budianto. Edisi Keenam. Jilid 2. Jakarta: Bina Rupa Aksara.

Frensidy. 2009. Teori Online Ekonomi, Manajemen dan Pemasaran Jasa. Rineka Cipta. Jakarta

Ghozali, Imam. 2005. Aplikasi Analisis Multivariate dengan program SPSS. Badan Penerbit Universitas Diponegoro, Semarang

Hurriyati, Ratih. 2010. Bauran Pemasaran dan Loyalitas Konsumen. Alfabeta CV. Jakarta

Joyce. 2005. Periklanan, Komunikasi Pemasaran Terpadu. Ghalia. Jakarta

Kotler, Philip. 2000. Manajemen Pemasaran. Jilid1. Edisi Milenium. Jakarta: Prenhalindo.

Kotler, Philip dan Gary Amstrong. 2010. PrinsipPrinsip Marketing. Edisi Ketujuh. Jakarta: Salemba Empat
Kotler, Philip dan Gary Amstrong. 2012. DasarDasar Pemasaran. Edisi sembilan. Jakarta: PT. Indeks.

Kotler, Philip dan Kevin Lane Keller. 2008. Manajemen Pemasaran. Jilid 1. Edisi 13. Jakarta: Erlangga.

Kotler, Philip dan Kevin Lane Keller. 2012. Marketing Management. Edisi 14. Jakarta: Erlangga.

Lolo, Irwinda N.T. Andi. 2011. Pengaruh Marketing Mix Terhadap Keputusan Konsumen Yang Menabung ada PT. Bank Mandiri (Persero) Tbk., Cabang Makassar Kartini, (Skripsi Tidak Dipublikasikan). Makassar : Universitas Hasanuddin.

Malhotra, N.K., 2009, Riset Pemasaran, Edisi Keempat, Jilid 1, PT Indeks, Jakarta

Mowen, John et.al. 2001. Perilaku Konsumen. Penerbit Erlangga. Jakarta

Olson, Peter. 1999. Perilaku Konsumen dan Strategi Pemasaran. Edisi Empat. Erlangga

Rizal, Agus, 2010, Analisis Pengaruh Grup Referensi dan Keluarga Terhadap Keputusan Pembelian Ponsel Qwerty Terhadap Mahasiswa UIN Syarif Hidayatullah Jakarta, Jakarta:Universitas Islam Negeri Syarif Hidayatullah

Schiffman \& Kanuk. 2007. Perilaku Konsumen. Edisi 7. Alih Bahasa : Zoelkifli Kasip. Indeks. Jakarta.

Sulistyawaty, R. 2006. Perilaku Konsumen dalam Penggunaan Kartu Kredit di Wilayah DKI Jakarta. (Skripsi Tidak Dipublikasikan). Jakarta: Universitas Gunadharma.

Swastha, Basu. 2008. Manajemen Pemasaran Modern. Edisi 2. Cetakan 13. Lyberty. Yogyakarta.

Swastha, Basu dan Sukotjo. 2002. Pengantar Bisnis Modern. Penerbit Liberty. Jogjakarta.

Tambunan, Tulus. 2001. Perekonomian Indonesia : Teori dan Temuan Empiris. Ghalia Indonesia. Jakarta.

Tjiptono, Fandy. 2008. Strategi Pemasaran. Edisi Ketiga, Andi Offset. Yogyakarta.

Wibowo, Puspita Maya. Dan Karimah. 2012. Pengaruh Iklan Televisi dan Harga terhadap Keputusan Pembelian Sabun Lux.Jurnal Riset Manajemen sains Indonesia.

Zeithaml. 2006. Manajemen Pemasaran, Analisa Perencanaan, Implementasi. Salemba Empat. Jakarta. 